\begin{tabular}{|c|c|c|}
\hline - T & $\begin{array}{c}\text { European Association for the } \\
\text { Development of Renewable Energies, Environment } \\
\text { and Power Quality (EA4EPQ) }\end{array}$ & $\begin{array}{l}\text { International Conference on Renewable Energies and Power Quality } \\
\text { (ICREPQ'12) } \\
\text { Santiago de Compostela (Spain), 28th to 30th March, } 2012\end{array}$ \\
\hline
\end{tabular}

\title{
2.3 MW Biomass Steam Power Plant: Experimental and Thermodynamic Analysis
}

\author{
A. Gimelli ${ }^{1}$, A.Luongo ${ }^{2}$ \\ ${ }^{1}$ DIME - Departmant of Mechanical and Energy, Univ. degli Studi di Napoli Federico II, gimelli@ unina.it \\ ${ }^{2}$ Faculty of Engineering, Univ. degli Studi di Napoli Federico II, alessa.luongo@studenti.unina.it
}

\section{Abstract.}

The present paper shows the experimental and numerical analysis of a biomass plant from maximum power of 2.3 MW. This is a classical Steam Power Plant with a maximum pressure of 48 bar and a turbine inlet temperature of about $430{ }^{\circ} \mathrm{C}$ at the design point. The size is significantly smaller than the mean of this type of system [1], [2], [3], [4], but maintains a relative high value (about 22.9\%) of the Global Electric Efficiency.

The analysis was conducted using experimental data, collected directly on the Power Plant, at the Design Point, and thus validating thermodynamic models.

The difficulty in collecting the experimental data of this type of system, is mainly due to the enormous variability of the lower heating value of biomass, which involves a large variability of the load and then the operating parameters. Combustion simulation was validated by experimental data (Flue gas temperature, air flow, fuel flow) and the results allowed the evaluation of the biomass composition that is within the range reported in the literature [5].

Different Plant configurations were, numerically, evaluated to plug the power fluctuations due to variability of biomass. A $100 \mathrm{kWe}$ Natural Gas fuelled Micro-Gas Turbine (MGT) was numerically connected to the Biomass Steam Power Plant (BSPP) to evaluate the benefits on the power fluctuations and on the Global Electric Efficiency. A MGT thermodynamic scheme has been developed and, properly, validated with experimental data from literature [6] e [7]. It is designed to send the hot gases coming from the exit of the MGT in the combustion chamber of the main system, thus creating a MGT-ST Power Plant. Analysis of the results of this coupling has noticed an improvement in terms of efficiency and operational stability.

\section{Key words}

Biomass Power Plant, Thermodynamic Analysis of Thermochemical Processes, Steam Turbine, Micro-Gas Turbine.

\section{Introduction}

Biomass is a term for all organic material that stems from plants (including algae, trees and crops). Biomass is produced by green plants converting sunlight into plant material through photosynthesis and includes all landand water-based vegetation, as well as all organic wastes. The biomass resource can be considered as organic matter, in which the energy of sunlight is stored in chemical bonds. When the bonds between adjacent carbon, hydrogen and oxygen molecules are broken by digestion, combustion, or decomposition, these substances release their stored chemical energy. Biomass has always been a major source of energy for mankind and is presently estimated to contribute of the order 10$14 \%$ of the world's energy supply [8].

The processes currently used are divided into two categories: thermochemical processes and biochemical processes (Fig. 1). Among the main thermochemical processes we find the direct combustion, gasification and pyrolysis, while the biochemical processes are the aerobic and anaerobic digestion proceedings [1].

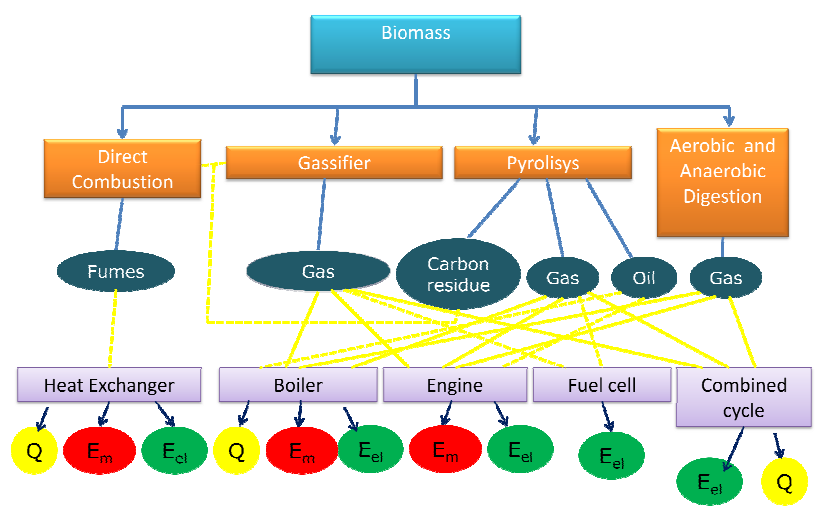

Fig. 1. Biomass Conversion Technologies Scheme.

Although the direct combustion is the most common form of energy conversion, it creates insuperable problems when the biomass humidity is high, in fact in these cases biomass can't be directly burned. This factor penalizes the production of direct combustion biomass 
energy because it is not always available low humidity biomass and the needed amount.

In this contest, it's important to consider Plants with low power, but the efficiency is penalized [3]. The present system has relative low power (2.3 MW) but it doesn't penalize very much the global electric efficiency (0.229 @ design point) [1], [2]. So, it's justified the interest to perform an experimental and numerical analysis of this relative small Steam Power Plant.

Also alternative layouts have been investigated to find solutions to reduce the mentioned problems about the humidity and relatives fluctuations.

These layouts have been numerically carried out through a thermodynamic and thermo-chemical analysis with Aspen Plus [9]. [10], [11].

\section{Description of Steam power plant}

As said, the steam power plant (scheme in Fig. 2) at design point generates $2.3 \mathrm{MWe}$ through direct combustion of woody biomass.

The plant (Fig. 2) consists of:

- Combustion chamber (CC Fig. 2) physically separated from the steam generator;

- Steam generator (GV Fig. 2), type vertical, natural circulation of water with vertical tubes, superheater and economizer;

- Steam turbine (T Fig. 2) is a 10 stages unit: the first one is an action stage and the others are the reaction stages. There is a bleed steam between the fifth and sixth stage;

- $\quad$ Flue gas cleaning system (F Fig.2) consists of a multi-cyclone and a bag filter;

- Condenser (C Fig. 2) at ground water.

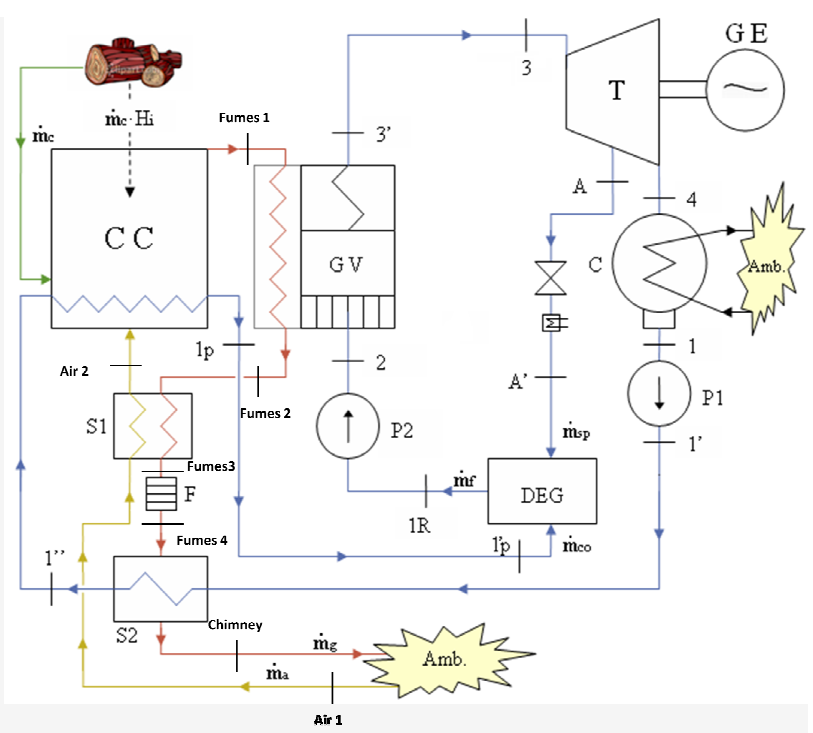

Fig. 2. Layout of Biomass Steam Power Plant (BSPP).

\section{Experimental analysis of Biomass Steam Power Plant (BSPP)}

The measurements of experimental data present some difficulties due to the continuous variation of the operating conditions. The biomass has a high humidity variability causing a change of LHV and, consequently, of operating conditions. The nominal point has been identified with numerous measurements and the relative operative conditions are reported in the Table I (more stable and repetitive values).

In the following chart (Chart 1), the continuous variation of the combustion chamber gas temperature generates bigger electric power variations. Combustion chamber temperature is, also, controlled by an EGR valve, but, as it can be seen from Chart 1, it's not sufficient to control the Power Stability.

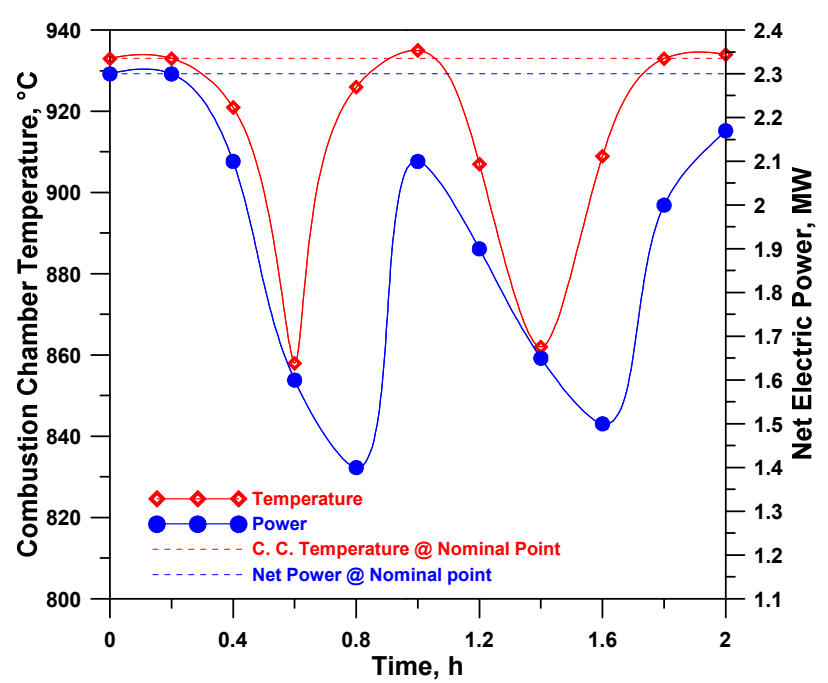

Chart 1. C.C. temperature trends and Power Generated.

The experimental data collected and used for energy analysis have been integrated with indirect data:

- Experimental data:

$>$ Ambient conditions: temperature, pressure (Table I);

> Steam Turbine: electric load, compression and expansion ratio, loss of load, temperature and pressure at various points of the thermodynamic cycle (Table I);

$>$ Boiler: mass flow temperature and pressure of the exhaust gas at various points;

- $\quad$ Indirect data (Table II and Table III):

$>$ Combustion efficiency: $\eta_{b}=\frac{P_{t, f}}{\dot{m}_{b} \cdot H_{i-b}}$

$>$ Efficiency of the Real Thermodynamic

Cycle: $\eta_{\text {ter }}=\eta_{\lim } \eta_{i}=\frac{P_{r}}{P_{t, f}}=\frac{P_{\lim }}{P_{t, f}} \frac{P_{r}}{P_{\lim }}$

$>$ Mechanical efficiency: $\eta_{m}=\frac{P_{u a}}{P_{r}}$

$>$ Global Efficiency: $\eta_{g}=\eta_{b} \cdot \eta_{t e r} \cdot \eta_{m}$

$>$ Global Electrical Efficiency:

$\eta_{\text {gel }}=\frac{P_{e, n e t}}{\dot{m}_{b} \cdot H_{i-b}}$

$>$ Composition and lower heating value of biomass (Table III). 


\begin{tabular}{|c|c|c|c|}
\hline \multicolumn{2}{|c|}{ Points Fig. 2} & Temperature $\left({ }^{\circ} \mathrm{C}\right)$ & Pressure (bar) \\
\hline \multirow{5}{*}{$\begin{array}{l}\text { Burned } \\
\text { Gas from } \\
\text { the SGCC }\end{array}$} & Fumes 1 & 933.0 & 0.998 \\
\hline & Fumes 2 & 262.4 & 0.998 \\
\hline & Fumes 3 & 171.3 & 0.998 \\
\hline & Fumes 4 & 171.3 & 0.998 \\
\hline & Chimney & 110.0 & 1.004 \\
\hline \multirow{10}{*}{$\begin{array}{l}\text { Water in } \\
\text { the } \\
\text { Thermo- } \\
\text { dynamic } \\
\text { Cycle }\end{array}$} & 1 & 24.1 & 0.030 \\
\hline & 1 & 24.1 & 3.000 \\
\hline & $1 "$ & 80.0 & 2.000 \\
\hline & $1 \mathrm{p}$ & 97.0 & 1.500 \\
\hline & $1 \mathrm{R}$ & 111.3 & 1.500 \\
\hline & 2 & 111.8 & 55.000 \\
\hline & 3 & 428.7 & 47.500 \\
\hline & $\mathrm{A}$ & 296.7 & 11.000 \\
\hline & $\mathrm{A}^{\prime}$ & 284.7 & 1.500 \\
\hline & 4 & 24.1 & 0.030 \\
\hline \multicolumn{2}{|c|}{ Air 1} & 21.7 & 1.004 \\
\hline \multicolumn{2}{|c|}{ Air 2} & 125.0 & 1.004 \\
\hline
\end{tabular}

Table I. - experimental conditions @ nominal point.

\begin{tabular}{|c|c|c|}
\hline & Experimental data & Simulation data \\
\hline$\eta_{b}$ & 0.903 & 0.905 \\
\hline$\eta_{t e r}$ & 0.341 & 0.342 \\
\hline$\eta_{m}$ & 0.806 & 0.805 \\
\hline$\eta_{g}$ & 0.248 & 0.249 \\
\hline$\eta_{e l}$ & 0.229 & 0.229 \\
\hline \multicolumn{3}{|c|}{ Table II. - Efficiencies @ Nominal Point. }
\end{tabular}

The evaluation of the biomass composition and its lower heating value was obtained iteratively with the help of a thermodynamic simulation software verifying that the composition assumed for the biomass and therefore the lower calorific value, realized the same operating conditions of the experimental data.

\begin{tabular}{|c|c|c|}
\hline & Water & $46.5 \%$ \\
\hline \multirow{4}{*}{$\begin{array}{c}\text { Average Biomass } \\
\text { Composition }\end{array}$} & Carbon & $33 \%$ \\
\cline { 2 - 3 } & Oxygen & $17 \%$ \\
\cline { 2 - 3 } & Hydrogen & $2 \%$ \\
\cline { 2 - 3 } & Nitrogen & $0.5 \%$ \\
\cline { 2 - 3 } & Ash & $1 \%$ \\
\cline { 2 - 3 } & $\mathrm{LHV}[\mathrm{MJ} / \mathrm{Kg}]$ & 14.6 \\
\hline
\end{tabular}

Table III. - Biomass Composition and Lower Heating Value.

\section{Thermodynamic model of Biomass Steam Power Plant}

A thermodynamic simulation of the plant (Fig. 2), energetic and chemical phenomena, has been carried out; the simulation scheme has been validated by experimental data. The simulation has been used to verify the biomass composition and LHV.

Have been supplied the following inputs:

- ST and Pumps Efficiencies;

- Temperatures and pressures of the working fluid in all the thermodynamic cycle (Table I);

- Heat Exchangers Sizes;
- Fuel and Combustion Air Flow and Composition; The outputs returned are the following:

- Flue Gas Temperature in the CC (Fig.2);

- Turbine Power Output;

- Thermal Power transferred from the flue gas to the motor fluid;

- Pumps Power;

- Efficiencies Values.

In particular, the flue gas temperature has been used as test. The tables (Table II and Table IV) show comparisons between the experimental and numerical flue gas temperatures (Table IV) and the comparison of efficiencies (Table II). It is clear that the composition assumed for the biomass is very close to the real mean value.

\begin{tabular}{|c|c|c|}
\hline & $\begin{array}{c}\text { Temperature } \\
\text { experimental } \\
\text { data }\left({ }^{\circ} \mathrm{C}\right)\end{array}$ & $\begin{array}{c}\text { Temperature } \\
\text { Simulation } \\
\left({ }^{\circ} \mathrm{C}\right)\end{array}$ \\
\hline Fumes 1 & 933.0 & 936.6 \\
\hline Fumes 2 & 262.4 & 261.4 \\
\hline Fumes 3 & 171.3 & 170.4 \\
\hline Fumes 4 & 171.3 & 170.4 \\
\hline Chimney & 110.0 & 109.3 \\
\hline
\end{tabular}

Table IV. - Flue gas temperatures comparison.

Different Plant configurations were, numerically, evaluated to plug the power fluctuations due to variability of biomass. A $100 \mathrm{kWe}$ Natural Gas fuelled MGT was numerically connected to the BSPP. It is designed to send the hot gases coming to the discharge of the MGT, in the combustion chamber of the main system, thus realizing a MGT-ST.

\subsection{Turbec 100 kWe MGT Validation Model}

To analyze different Plant layouts, a thermodynamic model of the MGT (Fig. 3) has been implemented. It has been validated with experimental data from literature ([6] and [7]).

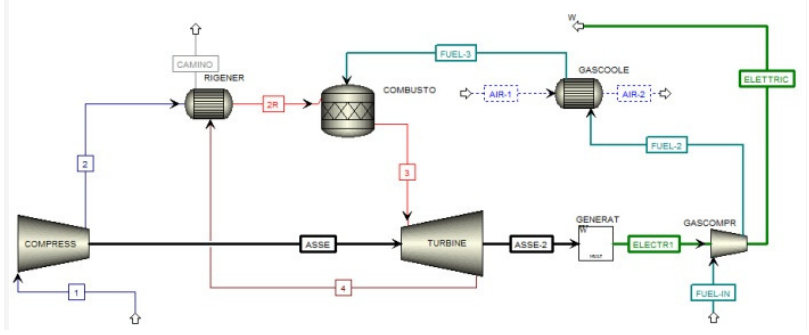

Fig. 3. TURBEC 100kWe MGT model.

Input simulation data are reported in Table V. Validation is confirmed by the good approximation between experimental and numerical comparison reported in the Table VI. A natural gas supply compressor has been considered because is necessary a pressure of $6-8$ bar to introduce the NG in the Combustion Chamber. This compressor is electrically powered and, therefore, it results a reduction of net electrical power output. It has been, also, necessary to introduce an air exchanger to cool the exit gas from the compressor because a feed gas temperature between $0{ }^{\circ} \mathrm{C}$ and $60{ }^{\circ} \mathrm{C}$ is required. 


\begin{tabular}{|c|c|}
\hline & Input \\
\hline \multirow{5}{*}{ Inlet Air } & $\mathrm{T}_{1}=20^{\circ} \mathrm{C}$ \\
\hline & $\mathrm{P}_{1}=1,01 \mathrm{bar}$ \\
\hline & $\dot{m}_{\text {air }}=0,808 \mathrm{~kg} / \mathrm{s}$ \\
\hline & $\mathrm{O}_{2}=22 \%_{\text {mass }}$ \\
\hline & $\mathrm{N}_{2}=78 \%$ mass \\
\hline \multirow{3}{*}{ Compressor } & $\beta=3,9$ \\
\hline & $\eta_{\mathrm{pol}}=0,82$ \\
\hline & $\eta_{\text {mecc }}=0,98$ \\
\hline \multirow{2}{*}{ Regenerator } & $\mathrm{T}_{2 \mathrm{R}}=632^{\circ} \mathrm{C}$ \\
\hline & $\mathrm{U}_{\mathrm{mid}}=44.5 \mathrm{~W} / \mathrm{m}^{2} \mathrm{~K}$ \\
\hline \multirow{9}{*}{ Fuel } & $\mathrm{T}_{\text {fuel }}=25^{\circ} \mathrm{C}$ \\
\hline & $\mathrm{P}_{\text {fuel }}=6 \mathrm{bar}$ \\
\hline & $\dot{m}_{\text {fuel }}=0,0068 \mathrm{~kg} / \mathrm{s}$ \\
\hline & $\mathrm{N}_{2}=0,029 \%_{\mathrm{vol}}$ \\
\hline & $\mathrm{CH}_{4}=0,92 \%_{\mathrm{vol}}$ \\
\hline & $\mathrm{C}_{2} \mathrm{H}_{6}=0,037 \%$ vol \\
\hline & $\mathrm{C}_{3} \mathrm{H}_{8}=0,01 \%_{\mathrm{vol}}$ \\
\hline & $\mathrm{C}_{4} \mathrm{H}_{10}=0,0025 \%$ vol \\
\hline & $\mathrm{CO}_{2}=0,0015 \%_{\mathrm{vol}}$ \\
\hline Boiler & $\mathrm{P}_{3}=3,67$ bar \\
\hline \multirow{3}{*}{ Turbine } & $\mathrm{P}_{\text {mecc. net }} \approx 110 \mathrm{~kW}$ \\
\hline & $\eta_{\text {isoentropic }}=0,85$ \\
\hline & $\eta_{\text {mecc }}=0,97$ \\
\hline
\end{tabular}

Table V. - Input data for MGT simulation.

\begin{tabular}{|l|l|l|}
\hline & \multicolumn{1}{|c|}{ Simulation output } & \multicolumn{1}{c|}{$\begin{array}{c}\text { Experimental } \\
\text { data }\end{array}$} \\
\hline 1 & $\begin{array}{l}\mathrm{T}_{1}=195,9^{\circ} \mathrm{C} \\
\mathrm{P}_{1}=3,94 \mathrm{bar}\end{array}$ & $\begin{array}{l}\mathrm{T}_{1}=195^{\circ} \mathrm{C} \\
\mathrm{P}_{1}=3,9 \mathrm{bar}\end{array}$ \\
\hline $2 \mathrm{R}$ & $\begin{array}{l}\mathrm{T}_{2 \mathrm{R}}=632^{\circ} \mathrm{C} \\
\mathrm{P}_{2 \mathrm{R}}=3,86 \mathrm{bar}\end{array}$ & $\mathrm{T}_{2 \mathrm{R}}=632^{\circ} \mathrm{C}$ \\
\hline 3 & $\begin{array}{l}\mathrm{T}_{3}=950,1^{\circ} \mathrm{C} \\
\mathrm{P}_{3}=3,67 \mathrm{bar}\end{array}$ & $\mathrm{T}_{3}=950^{\circ} \mathrm{C}$ \\
\hline Chimney & $\begin{array}{l}\mathrm{T}_{4}=676,7^{\circ} \mathrm{C} \\
\mathrm{P}_{4}=1,056 \mathrm{bar}\end{array}$ & $\mathrm{T}_{4}=678^{\circ} \mathrm{C}$ \\
\hline Compressor & $\mathrm{P}_{\text {camino }}=1,01 \mathrm{bar}$ & $\mathrm{T}_{\text {chimney }}=257^{\circ} \mathrm{C}$ \\
\hline Regenerator & $\begin{array}{l}\mathrm{P}_{\text {exchanged }}=381 \mathrm{~kW} \\
\text { Area }=164 \mathrm{~m}^{2}\end{array}$ & Area $=164 \mathrm{~m}^{2}$ \\
\hline
\end{tabular}

Table VI. - MGT Exper. and Numer. outputs data comparison.

Under rated operating the simulation returns the following performance values (Table VII):

\begin{tabular}{|c|c|}
\hline $\begin{array}{c}\text { Mechanical power } \\
\text { required by the compressor }\end{array}$ & $147,97 \mathrm{~kW}$ \\
\hline $\begin{array}{c}\text { Mechanical power } \\
\text { produced by the turbine }\end{array}$ & $257,37 \mathrm{~kW}$ \\
\hline Net mechanical power axis & $109,5 \mathrm{~kW}$ \\
\hline Electric power produced & $100,1 \mathrm{~kW}$ \\
\hline Net electric power & $97,5 \mathrm{~kW}$ \\
\hline$\eta_{\mathrm{el}}$ Electric efficiency & $31.1 \%$ \\
\hline
\end{tabular}

Table VII. - Characteristic values of MGT.

\subsection{Numerical analysis of the first alternative layout}

A numerical analysis of the system MGT-ST has been carried out, sending the microturbine exhaust gas to the combustion chamber of the BSPP.

The verification of the usefulness of this connection has been made by varying the mass flow of biomass and air introduced into the cycle, leaving constant the mass flow of flue gas at the exit of the combustor and without changing the design point of the steam cycle.

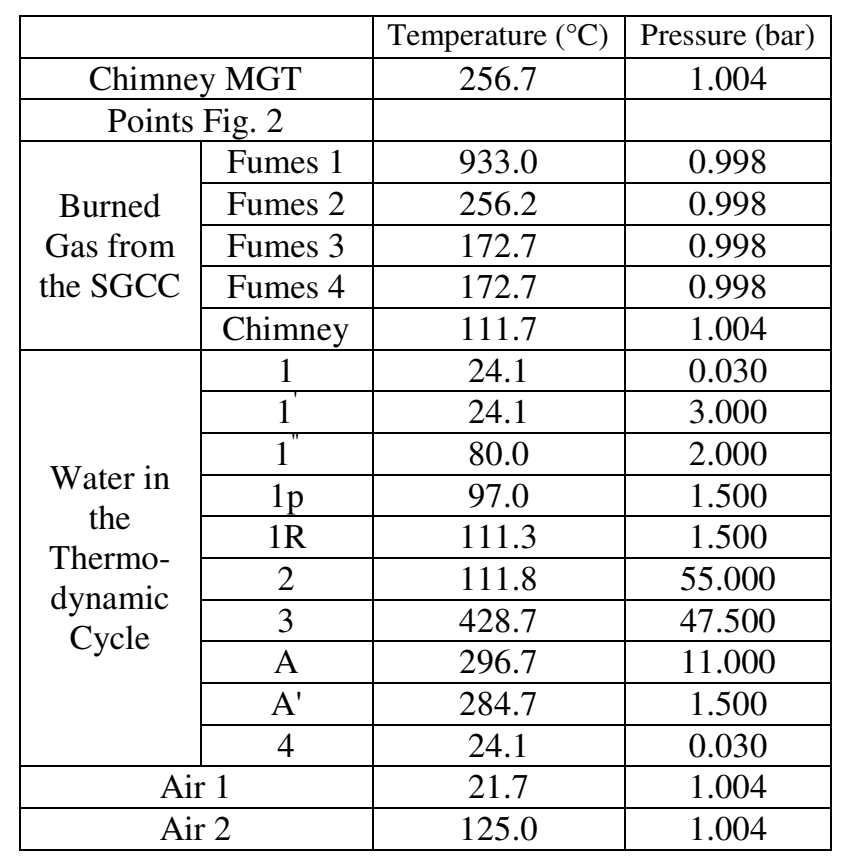

Table VIII. - MGT-ST cycle data.

Table VIII shows the characteristic points of the new cycle; thermodynamic cycle design point is the same and a small variation is found in the exhaust temperature which is slightly higher due to the reduced flow of heated air from the flue gases before entering the combustion chamber.

\begin{tabular}{|c|c|c|c|}
\hline & MGT & BSPP & MGT-ST \\
\hline $\begin{array}{c}\text { Biomass mass flow, } \\
\mathrm{kg} / \mathrm{s}\end{array}$ & - & $\mathbf{0 . 6 9 4}$ & $\mathbf{0 . 6 8 2}$ \\
\hline NG mass flow, kg/s & $\mathbf{0 . 0 0 6 8}$ & - & $\mathbf{0 . 0 0 6 8}$ \\
\hline Net electric power, $\mathrm{kW}$ & $\mathbf{9 7 . 5}$ & $\mathbf{2 3 6 8}$ & $\mathbf{2 4 6 5 . 5}$ \\
\hline Electric efficiency & $\mathbf{3 1 . 1 \%}$ & $\mathbf{2 2 . 9 \%}$ & $\mathbf{2 3 . 9 \%}$ \\
\hline
\end{tabular}

Table IX. - Different layouts comparison.

The biomass mass flow was reduced of $1.7 \%$, from 0,694 $\mathrm{kg} / \mathrm{s}$ to $0.682 \mathrm{~kg} / \mathrm{s}$, and the ratio between the mass flow 
of natural gas and biomass of $1 \%$. The total electric power (2465.5 $\mathrm{kWe}$ ) produced is higher and, also, the MGT-ST electrical efficiency is about $1 \%$ higher than the BSPP.

The comparison between different layouts is synthesized in Table IX.

\subsection{Numerical analysis of the second alternative layout}

Another possible layout that could to adjust the oscillation of electric power generated is a connection to a pulper paper gasification plant (more details are in [12]) with a biomass steam turbine power plant (Fig. 4).

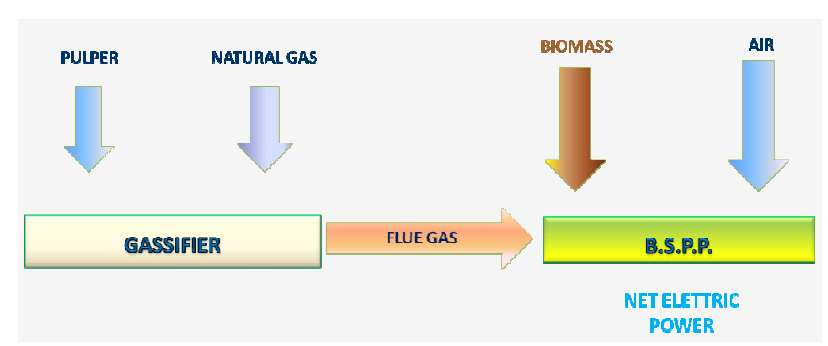

Fig. 4. Gassifier-BSPP layout.

In particular, it has been referred to the hot gases coming out of the heat treatment line (position 6 in Fig. 5), that are sent to steam power plant combustion chamber (CC Fig. 2).

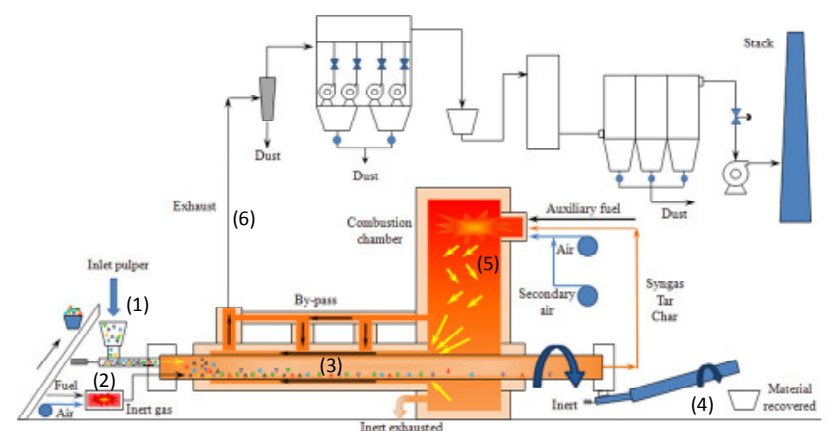

Fig. 5. Scheme of Gasification Plant

\begin{tabular}{|l|c|}
\hline Biomass mass flow & $1481 \mathrm{~kg} / \mathrm{h}$ \\
\hline Gross electric power & $2688 \mathrm{kWe}$ \\
\hline Electric power for pumps and auxiliary & $320 \mathrm{kWe}$ \\
\hline Net electric power & $2368 \mathrm{kWe}$ \\
\hline Electric efficiency & $23 \%$ \\
\hline
\end{tabular}

Table X. - Gassifier-BPP layout characteristics.

In this connection was preserved constant design point of the steam cycle and thus electrical power generated, while reducing the input biomass mass flow. The biomass was reduced to $1481 \mathrm{~kg} / \mathrm{h}$ (reduction of $40.7 \%$ ).

Evaluating the electrical efficiency ("waste" is referred to the Paper Industry Waste, "NG" to the Natural used in the Gassification Plant) as the ratio:

$$
\eta_{\text {gel } 2}=\frac{P_{e, \text { net }}}{\dot{m}_{\text {Waste }} \cdot H_{i-\text { Waste }}+\dot{m}_{N G} \cdot H_{i-N G}+\dot{m}_{b} \cdot H_{i-b}}
$$

a value of $15.5 \%$ has been obtained.
This result may appear low but it's necessary to consider that the flue gas leaving the gassifier would be lost. In fact, if it is considered the ratio excluding the Paper Industry Waste, the following ratio reaches:

$\eta_{g e l_{2}}^{*}=\frac{P_{e, n e t}}{\dot{m}_{N G} \cdot H_{i-N G}+\dot{m}_{b} \cdot H_{i-b}}$

the value of $26.2 \%$

Another possible layout could be to use the gasification system for biomass.

In this case the system would be totally powered by biomass.

\section{Conclusion}

An experimental and numerical analysis of a Biomass Steam Power Plant is presented. This Power Plant has relative low power (2.3 MW) but it doesn't penalize very much the global electric efficiency (0.229 @ design point). Experimental tests show the high variability of the Power output; that is due to the high oscillation of the biomass humidity.

The thermodynamic method is presented to find alternative lay-outs to solve this problem.

The first one, that utilizes a MGT, could increase the global electric efficiency, but it's necessary only use precious fuels (NG or high Lower Heating value Syngas). The second one could be interesting because it could be recovered the energy of some wastes, in particular, high humidity biomass waste. So the useful biomass for the BSPP could be extended.

\section{Acronyms and Symbols}

BSPP Biomass Steam Power Plant

SGCC Steam Generator Combustion Chamber

EGR Exhaust Gas Recirculation

LHV Lower Heating Values

MGT Micro-Gas Turbine

MGT-ST Micro-Gas turbines - Steam Turbine

NG Natural Gas

ST Steam Turbine

\section{Symbols}

Latins

$\begin{array}{ll}\dot{m}_{b} & \text { Biomass Mass Flow Rate } \\ \dot{m}_{\text {Waste }} & \text { Paper Industry Waste Mass Flow Rate } \\ \dot{m}_{N G} & \text { Natural Gas Mass Flow Rate } \\ H_{i-b} & \text { Biomass Lower Heating Value } \\ H_{i-\text { Waste }} & \text { Paper Industry Waste Lower Heating Value } \\ H_{i-N G} & \text { Natural Gas Lower Heating Value } \\ P_{\lim } & \text { Power of the Ideal Thermodynamic Cycle } \\ P_{r} & \text { Power of the Real Thermodynamic Cycle }\end{array}$


$P_{t, f} \quad$ Thermal Power given to the vector cycle fluid

$P_{u a} \quad$ Net Mechanical Power on the shaft

$P_{e, \text { net }} \quad$ Net Electric Power Generated

Greacs

$\eta_{b} \quad$ Combustion Efficiency

$\eta_{g} \quad$ Global Efficiency

$\eta_{g e l} \quad$ Global Electrical Efficiency

$\eta_{\text {gel2 }} \quad$ Global Electrical Efficiency for the $2^{\circ}$ alternative lay-out

$\eta_{i} \quad$ Internal Efficiency of all Plant Machines

$\eta_{\lim } \quad$ Efficiency of the Ideal Thermodynamic Cycle

$\eta_{m} \quad$ Mechanical Plant Efficiency

$\eta_{t e r} \quad$ Efficiency of the Real Thermodynamic Cycle

\section{References}

[1] A. Demirbas, "Biomass resource facilities and biomass conversion processing for fuels and chemicals", Energy Conversion and Management, Trabzon 2001.

[2] P. McKendry, "Bioresource technology, Energy production from biomass (part 2): conversion technologies", UK 2002.

[3] 1996-Broek et al-Biomass combustion for power generation.

[4] 1998-Purvis et al, "SMALL SCALE BIOMASS FUELED GAS TURBINE POWER PLANT",

[5] Adrisano-Berti, Monti e boschi, Potere calorifico superiore di alcune fra le più diffuse specie forestali del bosco ceduo, 1977.

[6] R.Tuccillo, RTO-EN-AVT, Performance and Transient Behaviour of MGT Based Energy System, France 2005.

[7] Technical documentation microturbine Turbec T100.

[8] P. McKendry, Bioresource technology, Energy production from biomass (part 1): Overview of biomass, UK 2002.

[9] Aspen Plus, User Guide version 10.2.

[10] Aspen Plus, Unit Operation Models version 10.

[11] Aspen Plus, Physical Property, Methods and models version 10.2

[12] A.Gimelli, A.Luongo, A.Amoresano System for the disposal of industrial waste gasification and energy generation: Experimentation and thermodynamics analysis, ICREPQ'12 